\section{Partnerships preserve water quality of Monterey Bay National Marine Sanctuary}

\author{
Holly Price a Richard M. Starr
}

The Monterey Bay National Marine Sanctuary is adjacent to more than 360 miles of coastline and is vulnerable to pollutants that can be transported from the cities, harbors and watersheds in the region. Small individual sources of pollution from scattered urban, suburban and agricultural activities build upon one another as water travels downstream and join with pollutants generated by marina and boating activities at the coastline. Recognizing that water quality is a key for protection of all natural resources, we helped create and organize a Water Quality Protection Program for the Monterey Bay National Marine Sanctuary. Key water quality issues identified in the sanctuary and its watersheds include sedimentation, toxic pollutants in sediments, fish and shellfish, oil and grease, high bacteria levels, fish population declines and wetlands and riparian degradation. The goal of the program is to develop partnerships to address these existing and potential problems, protect the sanctuary's current high level of water quality and prevent the kinds of expensive crises that have occurred elsewhere in the world.

To achieve success for this program, we formed a working committee of 27 federal, state and local agencies and public and private groups and use public workshops to identify potential problems and address water quality issues. We recently completed a series of planning documents to address water quality issues in urban areas and in harbors and marinas. Committee planning documents emphasized communication and coordination, education, and watershed stewardship, rather than regulation, as solutions for water quality problems. These plans are now being carried out in collaboration with a variety of groups.

The program is now focusing on agricultural issues. Key needs derived from three initial

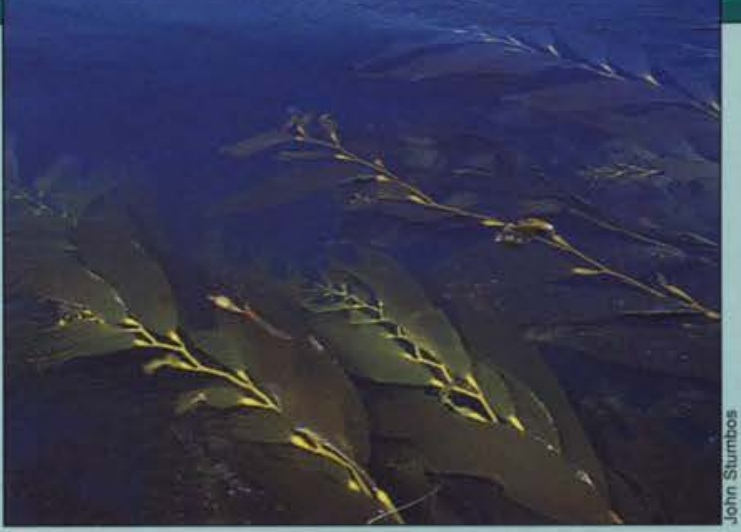

Kelp forests are an essential food resource and provide critical habitat for a number of species in the Monterey Bay National Marine Sanctuary.

workshops with farmers and ranchers include more extensive technical assistance and education; improved coordination of existing regulations; and development of incentives for conservation practices. We are in the beginning stages of problem solving with the agricultural industry and want to encourage the participation of all growers and ranchers. Participation is essential to ensure that solutions are developed that protect the environment and sustain the economic viability of the industry.

We hope that the Water Quality Protection Program for the sanctuary will serve as a model of how cooperative interactions among diverse interests can solve growing problems. This model uses the interests and knowledge of diverse stakeholders to evaluate issues based on environmental benefits, economic impacts and feasibility of proposed management. This approach may also be used to solve other problems facing the sanctuary, such as vessel traffic and the resulting potential for oil spills; increased population growth and human use of the coastal margin; and the ecological effects of intensive commercial and recreational fishing. The long-term success of the sanctuary program will depend on collaborative partnerships with diverse parties to protect and sustain the region's environmental and economic viability.

H. Price is Water Quality Protection Program Director, Monterey Bay National Marine Sanctuary, and R.M. Starr is UC Cooperative Extension, Sea Grant Marine Advisor for Monterey and Santa Cruz Counties.

For more information contact Holly Price, Water Quality Protection Program Director, Monterey Bay National Marine Sanctuary, 299 Foam St., Suite D, Monterey, CA, 93940. Phone (408) 647-4247. 